\title{
PENAFSIRAN TERMA NUN, AL-QALAM, DAN YASTHURUN DALAM AL-QUR'AN (ANALISIS SEMIOTIK)
}

\author{
Zahwa Amaly Fiddaraini \\ e-mail: zahwa.fiddaraini@gmail.com \\ Universitas Islam Negeri Sunan Kalijaga Yogyakarta \\ Muhammad Ariffur Rohman \\ e-mail:muhammadariffur@gmail.com \\ Universitas Islam Negeri Sunan Kalijaga Yogyakarta
}

\begin{abstract}
Abstrak: Penelitian ini bertujuan untuk mengkonstruksi makna bahasa al-Qur'an dengan system tanda. Penelitian ini menggunakan pendekatan semiotika. Berdasarkan pembacaan semiotika terhadap penafsiran tiga terma yang terdapat dalam surat al-Qalam ayat satu, penulis menemukan bahwa dengan pembacaan menggunakan teori aksis paradigmatic dan aksis sintagmatis, nun merupakan bagian dari huruf-huruf abjad, yang terletak pada permulaan sebagian surat alQur'an seperti halnya Aliflâmmîm, Aliflâmrâ, Aliflaammîmshâd dan sebagainya, yang merupakan bagian dari huruf-huruf abjad yang terletak di awal surah atau yang biasa disebut buruf al-Muqatha'ah. Dengan pembacaan menggunakan teori interaksi antar tanda/metafora dan metonim, nun adalah 'bak tinta', tempat menyimpan tinta yang merupakan kelengkapan pena untuk menulis, nun juga dimaknai sebagai sungai di surga. Adapun dengan pembacaan menggunakan teori heuristic dan pembacaan retroaktif/pembacaan secara semantic serta pembacaan secara hermeneutic, nun adalah malaikat yang diperintahu ntuk mengguankan pena untuk menulis. Nun ialah malaikat yang melukis semua kejadian pada lembaran atau kanvas tempat menuangkan tulisan. Jadi, nun wa alqalamwa ma yasturun adalah hierarki antara Tuhan dan makhluk-Nya.
\end{abstract}

Kata Kunci: Nun, al-qalam, Yasthurun, al-Qur'an, Analisis Semiotik

\begin{abstract}
This study aims to construct the meaning of Al-Qur'an language with a sign system. This study used a semiotic approach. Based on the semiotic reading of the interpretation of three terms contained in surah al-Qalam verse one, the writer found that reading using paradigmatic axis and the syntagmatic axis theories, nun was a part of alphabet, located at the beginning of some al Quran surahs such as Aliflâmmîm, Aliflâmrâ, Aliflaammimshâd, a part of alphabet that are located at the beginning of the surah that commonly called al-Muqatha' ab letters. With the reading using interaction theory between signs/metaphors and metonyms, nun is an 'ink bath', a place to store ink for pens for writing, nun is also interpreted as a river in heaven. As with reading using heuristic theory and retroactive reading/semantic reading and hermeneutic reading, nun is an angel which is ordered to use a pen to write. Nun is an angel who paints all events on a sheet or canvas. So, nun wa al-qalamwa ma yasturun is a hierarchy between God and His creatures.
\end{abstract}

Keywords: Nun, al-Qalam, Yasthurun, al-Qur'an, Semiotik Analysis. 


\section{PENDAHULUAN}

Ayat-ayat dalam al-Qur'an merupakan ekspresi linguistik dari bahasa Arab. Fenomena pembentukan bahasa merupakan konvensi antara parole (ekspresi bahasa) dan langue (sistem pembedaan antara tanda-tanda) yang membentuk sistem bahasa yang harus diikuti aturan dan ketentuannya, sehingga regulasi sistem bahasa akan lebih berkembang sejalan dengan perkembangan interaksi sosial masyarakat tutur dengan lingkungan sekitar. Bahasa merupakan korelasi sintagmatik antara penanda dan petanda yang bekerja sehingga membuahkan sintesa makna. Kenyataan langue adalah produk sosial budaya, dalam pengertian bahwa ia secara terus menerus ditempa di dalam praktik komunikasi yang di dalamnya langue dipelihara prinsip dasarnya, akan tetapi sekaligus diubah secara evolusioner. Konsekuensinya adalah bahwa langue tidak dapat berdiri sendiri secara otonom dalam kaitannya dengan parole, melainkan saling mempengaruhi secara timbal balik. Dengan kata lain, struktur dan relasi bahasa dalam semiotika signifikasi tidak bersifat permanen, melainkan subjek dan transformasi historis ketika ia digunakan di dalam semiotika komunikasi (Piliang, 2012: 269).

Diskursus semiotika al-Qur'an merupakan refleksi atas konvensi bahasa dalam tataran semantis yang berupaya mengakomodir konstruksi-konstruksi pemaknaan ulang suatu kata. Bahasa alQur'an merupakan salah satu variasi yang dapat dikaji baik secara heuristik maupun retroaktif. Pembacaan heuristik adalah pembacaan berdasarkan struktur kebahasaan atau berdasarkan sistem semiotik tingkat pertama (Pradopo: 80). Mekanisme kerja model pembacaan ini adalah dengan menekankan sistem kerja antara penanda dan petanda sehingga mampu menghasilkan makna reproduktif dalam satuan wacana. Pembacaan model ini sangat diperlukan guna mencari meaning dalam satuan medan linguistik baik dari sisi morfologi, sintaksis, maupun semantik. Kontekstualisasi meaning yang dimunculkan adalah sebatas kebenaran linguistik baik secara sinkronis maupun diakronis. Sedangkan, pembacaan retroaktif adalah upaya analisis teks untuk memperoleh maknanya dilihat aspek hubungan internal teks (ayat-ayat), intekstualitas, kontekstualitas, latar belakang, kritik sejarah dan perangkat studi Ulūm al-Qur'ān lainnya yang berkaitan dengan konvensi-konvensi di luar konvensi linguistic (Imran: 49). Model pembacaan ini lebih dikenal dengan model pembacaan tingkat kedua. Model pembacaan kedua ini dirasa lebih luas cakupannya. Seorang interpreter yang berusaha menggali makna secara holistik akan lebih tepat menggunakan model pembacaan tingkat kedua. Berbeda dengan model pembacaan tingkat pertama, yang hanya menekankan pada mekanisme kerja antara penanda dan petanda dalam tingkat meaning.

Kata "Semiotika" barasal dari bahasa Yunani "seme", seperti dalam semeiotikos, yang berarti penafsir tanda (Imran, 2011: 9). Sebagai suatu disiplin, semiotika berarti ilmu (teori) tentang lambang dan tanda (rambu-rambu lalu lintas, kode morse, sandi). Perintis awal semiotika adalah Plato (427 SM) yang memeriksa asal-muasal bahasa dalam Cratylus. Juga Aristoteles yang mencermati kata benda dalam bukunya Poetics dan On Interpretation (Imran, 2011: 9). Kata semiotika juga memiliki kemiripan makna dengan kata سيم dalam bahasa Arab. Kata tanda dalam al-Quran disebut سيما, sebagaimana dalam Q.S alFath/48: 29. "Tanda-tanda mereka tampak pada muka mereka dari bekas sujud." Di samping itu, al-Quran banyak bercerita tentang tanda. Tanda dalam alQuran disebut juga al-Aayah contohnya dalam Q.S al-Mu'minun/23:50. "Dan telah Kami jadikan (Isa) putera Maryam 
beserta ibunya suatu bukti yang nyata bagi (kekuasaan Kami), dan Kami melindungi mereka di suatu tanah tinggi yang datar yang banyak terdapat padang-padang rumput dan sumber-sumber air bersih yang mengalir."

Salah satu pendekatan dalam studi al-Qur'an yang dapat digunakan dalam bentuk teoritis interprtetatif dalam bingkai linguistik adalah pendekatan semiotika. Kerangka dasar semiotika adalah disiplin keilmuan yang mengkaji fenomena sosial dan kebudayaan merupakan tanda. Disiplin semiotika, digagas oleh salah satu filsuf dan ahli logika berkebangsaan Amerika yaitu Charles S. Peirce. Peirce mengatakan bahwa tanda-tanda berkaitan dengan objek-objek yang menyerupainya, keberadaanya memiliki hubungan kausal dengan tandatanda atau ikatan konvensional dengan tanda-tanda tersebut (Berger, 2010: 244).

Dalam kajian sastra Arab, disiplin ilmu semiotika sering disebut dengan istilah al-simiya' (السيمياء), sebagaimana yang diterangkan dalam as-Sima' wa anNash al-Adabi :

إذا كانت السيمياء او نظام العلامات علم يبحث في اللغات، والاشارات وقد اعتبر "دوسوسير" الدلالات

$$
\text { التي تعبر عن الماني. }
$$

Juga sebagaimana disebutkan dalam al-Simiya' wa Ta'wil :

السيمياء التي غالبا ما تعرف بأها دراسة الإشارت

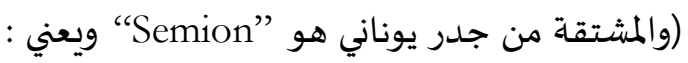

العلامة) هي دراسة الشفرات، اي الانظمة التئي

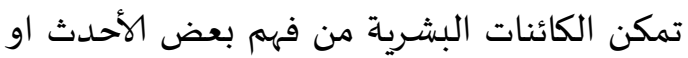

$$
\text { الوحدات بوضفها علامات تحمل معني. }
$$

(Ghonimi : 13). Dalam kamus "Lisan al-"Arab" karya monumental Ibn al-Manzhur, kata tersebut diberi makna menunjukkan kepada sesuatu atau tanda/isyarat (al-isyarah) (Manzhur, 1441H: 381). Para ilmuwan sastra Arab (Ubada') telah menaruh perhatian lebih terhadap kajian yang berkaitan dengan tanda atau isyarat ini. Dimana dalam berkomunikasi melalui isyarat tersebut, hanya mencukupkan pada tanda/isyarat yang ditunjukkan oleh tangan, mata dan anggota tubuh yang lainnya. Hal tersebut dimaksudkan untuk menunjukkan sesuatu yang sangat khusus dari sebuah makna. Oleh karenanya, tanda atau isyarat itu lebih dalam cakupan maknanya dibandingkan dengan makna yang terkandung dalam bentuk audio/suara (Al-Jahizh, 1998: 55).

Pendekatan semiotika dalam kajian al-Qur'an dapat dipergunakan jika alQur'an dipandang sebagai teks historis sehingga harus tunduk terhadap aturanaturan kebahasaan manusia. Al-Qur'an sebagai sebuah sistem tanda yang mempunyai kombinasi tanda tertentu sehingga memiliki makna tertentu mengharuskan adanya analisis terhadapnya untuk mengungkap maknamakna yang dikandungnya. Pendekatan semiotika dalam kajian al-Qur'an tentunya harus berdasarkan aturan-aturan dalam disiplin semiotika sebagaimana telah dan sedang berkembang (Rahtikawati, 2013: 380). Analisis terhadap al-Qur'an dengan pendekatan semiotika dapat dimulai dengan menganalisis stuktur bangunan kombinasi kode al-Qur'an. Pertama, analisis tanda secara individual seperti jenis tanda, mekanisme atau struktur tanda dan makna tanda. Dengan analisis ini, kita dapat mempergunakan, misalnya, tipologi tanda C.S. Peirce, yaitu indeks, ikon, dan simbol, atau juga model yang lainnya. Kedua, analisis tanda sebagai sebuah kelompok atau kombinasi, yaitu kumpulan tanda yang membentuk apa yang disebut sebagai teks. Analisis ini melibatkan apa yang disebut dengan rule of combination yang terdiri atas dua aksis, yaitu aksis paradigmatis dan aksis sintagmatis. Ketiga, interaksi antartanda yang dapat menggunakan metafora dan metonim. Metafora adalah interaksi tanda 
yang di dalamnya sebuah tanda dari sebuah sistem digunakan untuk menjelaskan makna sebuah sistem yang lainnya. Adapaun metonim adalah interaksi tanda yang di dalamnya sebuah tanda diasosiasikan dengan tanda lain yang di dalamnya terdapat hubungan bagian dengan keseluruhan (Rahtikawati, 2013: 351).

Semua analisis di atas penting dilakukan sebagai tafsiran restrospektif. Hal ini dilakukan dalam upaya untuk merekonstruksi makna atau kebenaran awal/orisinal. Untuk menghindari "kebekuan makna" jika dihadapkan dengan realitas kekinian, Derrida menawarkan tafsiran prospektif yang secara eksplisit membuka pintu bagi "indeterminasi makna" dalam sebuah permainan bebas (free play). Hal ini dimaksudkan untuk mengungkap hal-hal yang sepertinya tidak pernah terpikirkan (unthinkable) menjadi terpikirkan (thinkeble) atau yang tak terbayangkan (unimaginable) menjadi terbayangkan (imaginable) (Rahtikawati, 2013: 351). Pembacaan terhadap Al-Qur'an juga dapat dilakukan melalui dua tahap, yaitu pembacaan heuristik dan pembacaan retroaktif. Pembacaan heuristik adalah pembacaan berdasarkan konvensi bahasa, atau berdasarkan konvensi sistem semiotik tingkat pertama. Pembacaan retroaktif adalah pembacaan berdasarkan sistem semiotik tingkat kedua, atau berdasarkan konvensi di atas konvensi bahasa. Dua tahapan pembacaan di atas menghasilkan tingkatan makna yang berbeda. Dapat pula dikatakan bahwa pembacaan heuristik adalah pembacaan secara semantik, sedangkan pembacaan retroaktif adalah pembacaan secara hermeneutik.

Jika semiotika dirumuskan sebagai ilmu tanda atau signifikasi, pada prinsipnya al-Qur'an, sebagai salah satu unsur bahasa agama merupakan bidang subur bagi analisis semiotika. Pertama, dalam al-Qur'an, dunia ciptaan dengan berbagai aspeknya sering digambarkan sebagai tanda Allah, lebih tepat tanda kemahakuasaan atau kemahaesaan Allah. Kedua, al-Qur'an dapat dianggap sebagai himpunan tanda yang menujukkan makna tertentu yang dapat digali melalui proses interpretasi. Ketiga, teks al-Qur'an dianggap sebagai himpunan tanda yang menyampaikan pesan atau amanat Ilahi (le signifie dernier) (Mauleman, 1996: 39).

Ricouer menyebutkan bahwa simbol adalah seluruh ekspresi yang bermakna ganda dan makna utamanya tidak merujuk kepada dirinya sendiri, tetapi kepada makna kedua yang tidak pernah dibeberkan secara langsung (Sunardi, 1996: 45). Arkoun melihat adanya kesamaan dalam ketiga istilah ini; tanda, simbol dan mitos, yakni ketiganya memiliki fungsi untuk menunjukkan sesuatu di luar dirinya. Namun ia juga melakukan pembedaan antara tanda, simbol dan mitos. Tanda adalah sesuatu yang menunjukkan sesuatu lain di luar dirinya. Sedangkan simbol adalah sesuatu yanag merujuk pada sesuatu yang lain dan sesuatu yang lain itupun merujuk pada rujukan yang baru lagi. Kata merah, misalnya, adalah tanda bagi sesuatu yang memiliki warna tersebut. Namun kata merah tersebut bisa menjadi simbol bila sesuatu yang merah itu (makna dari tanda) dijadikan tanda lagi untuk hal yang lain, sifat pemberani misalnya. Sedangkan simbol bisa menjadi mitos bila simbol tersebut berada dalam sebuah cerita atau kisah (Sunardi, 1996: 81).

Diskursus semiotika al-Qur'an merupakan refleksi atas konvensi bahasa dalam tataran semantis yang berupaya mengakomodir konstruksi-konstruksi pemaknaan ulang suatu kata. Bahasa alQur'an merupakan salah satu variasi yang dapat dikaji baik secara heuristik maupun retroaktif. Pembacaan heuristik adalah pembacaan berdasarkan struktur kebahasaan atau berdasarkan sistem semiotik tingkat pertama (Pradopo, 2002: 80). Mekanisme kerja model pembacaan 
ini adalah dengan menekankan sistem kerja antara penanda dan petanda sehingga mampu menghasilkan makna reproduktif dalam satuan wacana. Pembacaan model ini sangat diperlukan guna mencari meaning dalam satuan medan linguistik baik dari sisi morfologi, sintaksis, maupun semantik. Kontekstualisasi makna yang dimunculkan adalah sebatas kebenaran linguistik baik secara sinkronis maupun diakronis. Sedangkan, pembacaan retroaktif adalah upaya analisis teks untuk memperoleh maknanya dilihat aspek hubungan internal teks (ayat-ayat), intekstualitas, kontekstualitas, latar belakang, kritik sejarah dan perangkat studi Ulum al-Qur'an lainnya yang berkaitan dengan konvensi-konvensi di luar konvensi linguistik (Imran, 2011: 49). Model pembacaan ini lebih dikenal dengan model pembacaan tingkat kedua. Model pembacaan kedua ini dirasa lebih luas cakupannya. Seorang interpreter yang berusaha menggali makna secara holistik akan lebih tepat menggunakan model pembacaan tingkat kedua. Berbeda dengan model pembacaan tingkat pertama, yang hanya menekankan pada mekanisme kerja antara penanda dan petanda dalam tingkat meaning.

Dalam artikel ini penulis akan meneliti tentang penafsiran para ulama terhadap terma nun, al-qalam dan yasthurun pada surat al-Qalam yang terdapat dalam ayat pertama. Penulis akan menggunakan teori aksis paradigmatik dan aksis sintagmatis. Penelitian ini bertujuan untuk menguji secara ilmiah tanda-tanda dan lambang-lambang verba. Penelitian ini berupaya untuk mengkonstruksi makna bahasa al-Qur'an dengan sistem tanda.

Sejauh pengetahuan penulis terdapat beberapa penelitian yang memiliki kesamaan baik dalam pendekatan dan teori yang digunakan, maupun objek kajian yang sama. Diantara penelitian tersebut adalah Kajian Semiotika dalam Penafsiran Al-Qur'an
(Hasan: 2016: 549-558). Penelitian tersebut mencoba untuk menganalisa efektifitas kajian semiotika dalam upaya menafsirkan ayat-ayat al-Qur'an guna mendapatkan nuansa penafsiran yang lebih komprehensif. Penelitian selanjutnya adalah Semiotika Al-Qur'an: Representasi Makna Verba Reflektif Perilaku Manusia Dalam Surat Al-Ma'un dan Bias Sosial Keagamaan (Hanafi, 2018, 15-30). Penelitian tersebut mendeskripsikan maknanya dalam bias sosial keagamaan. Metode yang digunakan adalah kualitatif interpretatif. Berikutnya penelitian dengan judul Pendekatan Semiotika dan Penerapannya dalam Teori Asma' Al-Qur'an (Lukman, 2015: 207-226). Penelitian tersebut melihat prinsip-prinsip semiotika dan bagaimana contoh penerapannya dalam studi al-Qur'an. Adapun yang membedakan penelitian ini dengan penelitan sebelumnya adalah penulis menggunakan pendekatan semiotik dengan teori Interaksi antartanda/metafora dan metonim dengan menggunakan hasil penafsiran para ulama terhadap terma yang terdapat dalam al-Quran surat al-Qalam ayat satu sebagai objek penelitiannya. Dengan demikian penelitian ini dapat dikatakan sebagai lanjutan dari penelitian-penelitian sebelumnya yang bersifat melengkapi.

Penelitian ini penting dilakukan sebagai upaya memberikan pemaknaan baru kepada ayat-ayat al-Qur'an yang sesuai dengan konteks zamannya dengan menggunakan ilmu-ilmu modern yang telah berkembang khususnya dalam bidang ilmu kebahasaan dan kesusastraan.

\section{METODE PENELITIAN}

Penelitian ini menggunakan pendekatan Semiotika. Metode semiotika pada dasarnya bersifat kualitatif-interpretatif (interpretation), yaitu sebuah metode yang berfokus kepada tanda dan teks sebagai objek kajiannya, serta bagaimana peneliti menafsirkan dan memahami kode (decoding) di balik tanda dan teks tersebut. 
Di antara salah satu metode interpretatif tersebut ialah metode deskriptif analitik, yakni dengan mendeskripsikan terlebih dahulu terma-terma penting kajian kemudian dilanjutkan dengan menganalisisnya satu persatu. Adapun metode yang penulis gunakan dalam penelitian ini adalah metode deskriptifanalitik yang mana penulis akan terlebih dahulu melakukan pendeskripsian terhadap terma-terma penting. Kemudian akan penulis lanjutkan dengan memaparkan dan menganalisisnya satupersatu terma-terma yang menjadi obek kajian dalam penelian ini.

Untuk mempertajam kajian penulis juga akan memaparkan pandanganpandangan para ahli baik dalam bidang semiotika maupun dalam bidang penafsiran ayat-ayat al-Qur'an, hal ini penulis anggap perlu untuk mencari titik temu setelah adanya perbandingan. Maka disamping dengan metode deskripif dan analitik penulis juga berupaya memaksimalkan metode komparatif.

Pengumpulan data merupakan salah langkah penting dalam melaksanakan penelitian. Melalui pengumpulan data, akan diperoleh informasi penting, sahih, dan terpercaya, sehingga hasil penelitian dapat dipertanggungjawabkan secara ilmiah. Tahapan pengumpulan data pada penelitian ini adalah dengan teknik dokumentasi, karena informasi yang dikaji bersumber dari dokumen, yakni kitab suci Al-Qur'an. Tahapan selanjutnya adalah analisis data, tahap ini merupakan tahapan yang menentukan, karena kaidahkaidah yang mengatur keberadaan objek penelitian harus sudah diperoleh. Penemuan kaidah-kaidah tersebut merupakan dari inti dari penelitian, betapapun sederhananya kaidah yang ditemukan. Data dianalisis dengan pendekatan kualitatif, data yang dianalisis secara kualitatif ini disajikan dalam bentuk uraian. Adapun analisis data pada penelitian ini dilakukan dengan cara menganalisis tanda individual. Kemudian langkah selanjutnya adalah analisis tipologi tanda, yaitu dengan mengidentifikasi verba reflektif dalam konvensi bahasa hingga satuan terbesar dengan berdasarkan objek semiotik. Setelah dilakukan tahapan analisis makna tanda, maka langkah selanjutnya adalah memunculkan makna denotasi tentang verba reflektif dalam pembacaan semiotis. Upaya ini merupakan langkah terakhir dalam sistem kerja tanda semiotika dalam merepresentasikan tanda-tanda dalam alQur'an.

\section{HASIL DAN PEMBAHASAN}

Sekilas tentang Surah al-Qalam

Al-Qalam merupakan jenis surah Makkiyyah, terdiri dari 52 ayat. Surat ini berisikan pembelaan terhadap Rasululah saw. dan pemantapan keinginan hatinya agar tetap teguh pada kebenaran tanpa harus mengalah pada siapa pun. Dalam surat ini, siksa yang diterima oleh penduduk Mekah dianalogikan dengan apa yang diderita oleh pemilik kebun yang ceritanya dituturkan di dalam surat ini. Diterangkan juga berita gembira untuk orang-orang Mukmin dari sisi Tuhan dan bahwa mereka itu tidak sama dengan orang-orang kafir. Selain itu, surat ini berisi penolakan terhadap kepalsuan para pendusta yang menyandangkan sesuatu yang tidak benar untuk diri mereka, ancaman terhadap mereka berupa penjelasan keadaan mereka di akhirat dan nasehat kepada Rasulullah SAW untuk selalu sabar dan tabah. Surah ini ditutup dengan keterangan tentang kemuliaan alQur'ân. Nun adalah salah satu huruf fonemis yang digunakan untuk memulai sebagian surat-surat al-Qur'ân sebagai tantangan kepada orang-orang yang mendustakannya dan gugahan terhadap orang-orang yang mempercayainya.

Al-Qalam adalah surat ke-68. Diturunkan di Makkah pada awal kenabian. Pada urutan kedua setelah surat al-'Alaq dan sebelum surat al-Muzammil. Sebagian ulama berpendapat urutannya 
terbalik, surat al-Muzammil pada urutan ke-2 dan al-Qalam sesudahnya. Nama surat ini al-Qalam. Mengingatkan pada surat sebelumnya, surat al-'Alaq, yang menyatakan bahwa Tuhan mengajarkan manusia dengan pena. Menarik bahwa kedua surat paling awal ini menyinggung peranan pena sebagai alat belajar mengajar. Kaya dan syarat dengan etos tradisi keilmuan. Surat ini diberi nama alQalam, yang berarti pena. Sebuah isyarat agar kaum Muslimin manjadi umat terdidik. Surat ini dimulai dengan huruf muqatha'at "Nûn". Disusul dengan sumpah pena. Huruf "Nûn". Sebagian ulama melambangkan tinta atau tempat tinta sebagai pasangan pena (Khoirudin, 2014: 20).

\section{Nun, Wa al-Qalami Wa Yasturun Menurut Para Mufasir}

Pandangan para mufassir tentang nun, al-qalam dan yasthurun sangat bervariatif. Tiga terma tersebut yakni "nun", "al-Qalam" dan "yasthurun" disebutkan secara berurutan pada ayat pertama dalam surat al-Qalam. Adapun beberapa pandangan para mufasir tentang tiga terma tersebut adalah sebagai berikut:

Al-Qalam merupakan jenis surat Makkiyyah, terdiri dari 52 ayat. Surat ini berisikan pembelaan terhadap Rasululah saw. dan pemantapan keinginan hatinya agar tetap teguh pada kebenaran tanpa harus mengalah pada siapa pun. Dalam surat ini, siksa yang diterima oleh penduduk Mekah dianalogikan dengan apa yang diderita oleh pemilik kebun yang ceritanya dituturkan di dalam surat ini. Diterangkan juga berita gembira untuk orang-orang Mukmin dari sisi Tuhan dan bahwa mereka itu tidak sama dengan orang-orang kafir. Selain itu, surat ini berisi penolakan terhadap kepalsuan para pendusta yang menyandangkan sesuatu yang tidak benar untuk diri mereka, ancaman terhadap mereka berupa penjelasan keadaan mereka di akhirat dan nasehat kepada Rasulullah SAW untuk selalu sabar dan tabah. Surat ini ditutup dengan keterangan tentang kemuliaan alQur'ân. Nûn adalah salah satu huruf fonemis yang digunakan untuk memulai sebagian surat-surat al-Qur'ân sebagai tantangan kepada orang-orang yang mendustakannya dan gugahan terhadap orang-orang yang mempercayainya.

Al-Qalam adalah surat ke-68. Diturunkan di Makkah pada awal kenabian. Pada urutan kedua setelah surat al-'Alaq dan sebelum surat al-Muzammil. Sebagian ulama berpendapat urutannya terbalik, surat al-Muzammil pada urutan ke-2 dan al-Qalam sesudahnya. Nama surat ini al-Qalam. Mengingatkan pada surat sebelumnya, surat al-'Alaq, yang menyatakan bahwa Tuhan mengajarkan manusia dengan pena. Menarik bahwa kedua surat paling awal ini menyinggung peranan pena sebagai alat belajar mengajar. Kaya dan syarat dengan etos tradisi keilmuan. Surat ini diberi nama alQalam, yang berarti pena. Sebuah isyarat agar kaum Muslimin manjadi umat terdidik. Surat ini dimulai dengan huruf muqatha'at "Nûn". Disusul dengan sumpah pena. Huruf "Nûn". Sebagian ulama melambangkan tinta atau tempat tinta sebagai pasangan pena (Khoirudin, 2014: 20).

\section{Makna Nun}

Para mufasir berbeda pendapat tentang arti huruf Nûn. Nûn ditafsirkan seperti huruf-huruf abjad. Huruf itu yang terletak pada permulaan sebagian suratsurat al-Qur'an seperti: Alif lâm mîm, Alif lâm râ, Alif laam mîm shâd dan sebagainya (Khoirudin, 2014: 21). Ada juga, di antara ahli-ahli tafsir yang menyerahkan pengertiannya kepada Allah. Karena dipandang termasuk ayatayat mutasyâbihât, dan ada pula yang berani menafsirkannya, dengan kehatihatian. Sementara itu, ada golongan yang menafsirkan Nûn. Mereka memandang Nûn sebagai nama surat. Huruf-huruf abjad itu gunanya untuk menarik perhatian. Supaya para pendengar memperhatikan al-Qur'an. Fungsinya 
untuk mengisyaratkan bahwa al-Qur'an itu diturunkan dari Allah dalam bahasa Arab. Al-Qur'an tersusun dari hurufhuruf abjad (hijaiyah) yang memiliki nilai sastra yang tinggi dan luar biasa. Seakan Allah sengaja menantang manusia. Jika manusia tidak percaya, al Qur'an diturunkan dari Allah. Al-Qur'an bukanlah karya Muhammad saw. Coba, manusia membuat kalimat semacam alQur'an. Tentu manusia tidak akan mampu.

Quraisy Shihab menafsirkan huruf Nûn sebagai salah satu huruf fonemis yang digunakan oleh al-Qur'an. Di sini Nûn digunakan sebagai pembuka. Sebagaimana pembuka surat-surat alQur'an lainnya. Penempatannya pada awal surat dipahami oleh sebagian ulama sebagai tantangan kepada orang-orang yang meragukan al-Qur'an sebagai kalam Allah. Dengan huruf-huruf tersebut seakan Allah berkata, Al-Qur'an terdiri dari kata-kata yang tersusun dari hurufhuruf fonemis yang kamu kenal, misalnya Nûn, atau alif, lam, mim. Cobalah buat dengan menggunakan huruf-huruf itu suatu susunan kalimat walau hanya sebanyak satu surat yang terdiri dari tiga ayat guna menandingi keindahan bahasa al-Qur'an. Pasti kamu akan gagal.

Hamka menafsirkan Nûn, bukan semata-mata huruf Nûn lengkung bertitik satu di atas, yaitu huruf yang ber-makhraj di pertemuan ujung langit-langit dan dikeluarkan melalui hidung, yang dinamai juga huruf sengau. Hamka menyebutkan bahwa Nûn adalah sebuah nama ikan besar di laut sebangsa ikan paus. Ikan itulah yang menelan Nabi Yunus. Ketika ia meninggalkan negerinya. Karena kecewa melihat kekufuran kaumnya. Penafsiran ikan bernama Nûn yang menelan Nabi Yunus ini oleh Hamka dihubungkan dengan ayat-ayat terahir dari surat ini, yaitu ayat 48, 49, dan 50. Karena tiga ayat tersebut menceritakan tentang Nabi Yunus yang ditelan ikan. Penafsiran ini dikuatkan oleh surah al-Anbiya ayat 87 menyebut Nabi Yunus dengan Zan Nûn. Menurut Ar-Razi tafsir demikian diterima dari Ibnu Abbas, Mujahid, Muqatil, dan As Suddi.

Bagi para sufi, ayat pertama surah Al-Qalam ayat 1, yaitu Nun, wa al-Qalam, wa $M a$ Yasthurun (Nun, demi pena dan apa yang dituliskannya), bermakna amat dahsyat. Misteri ayat ini diungkap para sufi dengan perspektif sangat berbeda dibanding makna dalam kitab-kitab tafsir kontemporer. Ternyata tiga komponen dalam ayat ini, yaitu nun, qalam, dan lembaran menjadi asal usul segala ciptaan Tuhan. Aziz al-Din Nasafi (Wafat $695 \mathrm{H} / 1295 \mathrm{M})$, seorang sufi dari Bani Kubrawi, yang pikirannya banyak dipengaruhi oleh Ibnu Arabi, menjelaskan bahwa nun adalah 'bak tinta'. Sedangkan qalam adalah pena, yang merupakan substansi pertama atau biasa disebut sebagai akal pertama, dan lembaran (ma yastburun) ialah lembaran yang terpelihara (lauh mahfuz) atau ummul kitab. Nun sebagai bak tinta adalah tempat menyimpan tinta, merupakan kelengkapan pena untuk menulis.

Nun dihubungkan dengan QS AlKahfi: 109, "Katakanlah: 'Kalau sekiranya lautan menjadi tinta untuk (menulis) kalimat-kalimat Tuhanku, sungguh habislah lautan itu sebelum habis (ditulis) kalimat-kalimat Tuhanku, meskipun Kami datangkan tambahan sebanyak itu (pula)'." Berbeda dengan Ibnu Arabi yang mengartikan nun dengan malaikat yang diperintah untuk menggunakan pena itu untuk menulis. Pendapat sama juga dikemukakan Imam Ja'far. Sebagian lagi mengartikan nun sebagai sungai di surga dan sejenis ikan yang pernah menyelamatkan Nabi Yunus. Bagi Ibnu Arabi, nun ialah malaikat yang melukis semua kejadian. Sang penulis memiliki pengetahuan majemuk dan beraneka ragam. Nun dan penanya aktif memberi pengaruh, sedangkan lembaran atau kanvas tempat menuangkan tulisan bersifat reseptif. Jadi, menurutnya, nun wa 
alqalam wa ma yasthurun adalah hierarki antara Tuhan dan makhluk-Nya.

\section{Makna al-Qalam}

Dalam al-Qur'an terdapat empat terma atau lafaz "al-Qalam” yakni pada surat Luqman ayat 27, al-Qalam ayat 1, alA'laq ayat 4 dan Ali Imran ayat 44. Berikut adalah redaksi ayat tersebut:

QS. Luqman: 27

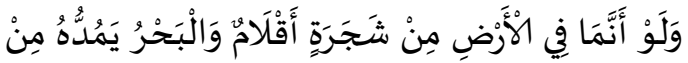

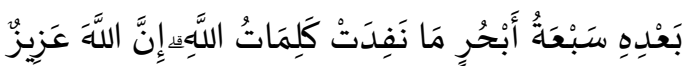

حَكِيمَ بعِ نَ

"Dan seandainya pohon-pohon di bumi menjadi pena dan laut (menjadi tinta), ditambahkan kepadanya tujuh laut (lagi) sesudah (kering)nya, niscaya tidak akan habis-habisnya (dituliskan) kalimat Allah. Sesungguhnya Allah Maha Perkasa lagi Maha Bijaksana."

Al-Qalam: 1

$$
\text { نَعَالْقَلَمِ وَمَا يَنْطُرُونَ }
$$

"Nun, demi kalam dan apa yang mereka tulis"

Al-A'laq: 4

$$
\text { الَّذِي عَلَّمَ بِالْقَلَمِم }
$$

"Yang mengajar (manusia) dengan perantaran kalam"

Ali Imran: 44

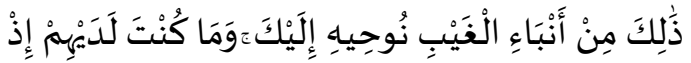

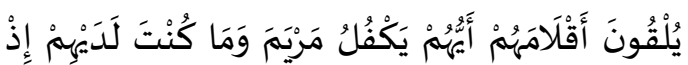

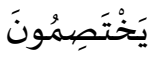

"Yang demikian itu adalah sebagian dari berita-berita ghaib yang Kami wahyukan kepada kamu (ya Muhammad); padahal kamu tidak hadir beserta mereka, ketika mereka melemparkan anak-anak panah mereka (untuk mengundi) siapa di antara mereka yang akan memelihara Maryam. Dan kamu tidak hadir di sisi mereka ketika mereka bersengketa."

Dalam Ibnu Katsir, kata "wal qalami" (demi kalam), secara lahiriyah berarti "demi pena". Allah bersumpah dengan pena. Alat yang digunakan untuk menulis. Seperti kata Allah dalam surat al-
'Alaq Ayat 4, "Dia yang mengajarkan dengan pena".

Wa al-qalam adalah sumpah Tuhan (qasm) pertama dalam Alquran yang turun tidak lama setelah lima ayat pertama: Iqra' bi ismi Rabbikalladzi khalaq, khalaqa al-insana min alaq, iqra' warabbuka al-akram, alladri 'allama bi al-qalam, 'allama al-insana ma lam ya'lam.

Pena atau kalam, sebagaimana juga disinggung dalam ayat keempat tadi, merupakan ciptaan Allah yang pertama dari tiada menjadi ada melalui kun fa yakun. Dalam sebuah hadis yang sering muncul dalam kitab-kitab tasawuf, pena ini diperintah dengan kata-kata, "Tulislah pada lingkaran pertama ini, yaitu lembaran Tuhan." Pena lalu menjawab, "Wahai Tuhan, apa yang harus aku tulis?" Perintah berikutnya muncul, "Tulislah segala sesuatu yang telah terjadi, yang sedang terjadi, dan yang akan terjadi hingga hari kebangkitan." Pena menulis semuanya, sesudah itu pena menjadi kering. "Tuhan telah selesai dengan penciptaan, persediaan, dan ketentuanketentuan yang pasti."

$$
\text { نَّ وَالْقَلَمِ وَمَا يَسْطُرُونَ (1) }
$$

"Nun, Demi pena dan apa yang mereka tulis." (Qs. al-Qalam [68]:1)

Qalam artinya alat menulis atau sesuatu yang dengannya dapat digunakan untuk menulis. Sedangkan lafadz yasthurun dalam ayat di atas merupakan kata kerja yang derivatnya adalah sa-tha-ra yang bermakna tersusunya kata per kata dalam satu halaman, tercabut sesuatu dari pohon, atau bermakna orang-orang yang berdiri. Tatkala disebutkan "sathara fulanu kadza" maknanya bahwa orang itu telah menulis baris (satr) demi baris (satr). AlMaraghi mengatakan bahwa Allah SWT bersumpah dengan kalam (pena) dan kitab untuk membuka pintu pengajaran dengan keduanya itu, karena Tuhan kita tidak akan bersumpah kecuali dengan urusan-urusan yang besar. Apabila Allah bersumpah dengan matahari dan bulan, malam dan fajar, maka itu disebabkan 
besarnya makhluk dan penciptaannya. Dan jika Dia bersumpah dengan qalam dan kitab, maka hal itu menunjukkan luasnya ilmu dan pengetahuan yang dengannya jiwa dididik.

Para mufassir memberikan kemungkinan lain bahwa yang dimaksud dengan qalam dan tulisan yang disebutkan dalam ayat ini boleh jadi mencakup salah satu batin dari batin al-Qur'an seperti yang disebutkan bahwa yang dimaksud dengan qalam adalah qalam penciptaan; karena qalam pertama adalah sebuah entitas yang diciptakan oleh Allah SWT. Dalam hadis disebutkan bahwa qalam merupakan entitas pertama yang diciptakan oleh Allah SWT.

Maka jika diteliti dengan menggunakan pendekatan semiotik berbagai macam pemaknaan terma alQalam yang telah dilakukan oleh para mufasir semua hanya melakukan spekulasi makna yang paling mendekati dengan apa yang dikehendaki oleh Allah Sang pemilik kalam (Ayat-ayat yang dimaksud dalam penelitian ini).

Dalam Tafsir al-Misbah, Al-Qalam berarti pena. Alat tulis apa pun termasuk komputer, laptop, gadget, dan tablet tercanggih. Ada yang berpendapat bahwa al-qalam bermakna pena tertentu. Seperti pena yang digunakan oleh para malaikat untuk menulis takdir baik dan buruk manusia. Pena pencatat segala kejadian yang tercatat dalam Lauh Mahfuz. Pena yang digunakan oleh para sahabat untuk menuliskan al-Qur'an. Pena yang digunakan untuk menuliskan amal baik dan amal buruk yang dilakukan manusia.

Baik qalam dengan makna penciptaan, pena, laptop, hape maupun dengan makna pena husus (alat unyuk mencatat di lauh al-Mahfudz) semua merupakan hasil pemaknaan yang melibatkan antara penanda dan petanda sebagai acuan dalam melahirkan intepretasi makna yang dianggap paling mendekati apa yang sebenarnya dikehendaki Allah Sang pemilik kalam.

\section{Makna Yasthurun}

Pemahaman tentang "wa mâ yasthurûn" yang berarti "dan apa yang mereka tulis" harus dikaitkan dengan makna al-qalam. Dengan demikian yang ditunjuk oleh kata "mereka" dapat dipahami dalam arti malaikat, sahabat Nabi, para penulis wahyu, atau manusia kita semua seluruhnya. Tidak begitu substatif tentang siapa "mereka". Karena yang terpenting ialah kata "tulis". Menurut Ar-Razi ada pula yang menafsirkan bahwa "mereka" disini ialah malaikat-malaikat yang menuliskan segala amal perbuatan manusia. Sebab dalam surah al-Infithar ayat 10, dan 11 tentang malaikat-malaikkat yang mulia yang ditugaskan oleh Allah menuliskan segala amal perbuatan manusia dan menjaganya. "Padahal sesungguhnya bagi kamu ada (malaikat-malaikat) yang mengawasi (pekerjaanmu), yang mulia (di sisi Allah) dan mencatat (pekerjaan-pekerjaanmu itu)."

Tentang pembahasan ini para ulama juga menyandarkan pemahamannya kepada hadist Rasulullah SAW. diriwayatkan oleh Ibnu Asakir, dari Abu Abdullah maula Bani Umayyah, dari Abu Saleh, dari Abu Hurairah, bahwa ia pernah mendenaar Rasulullah SAW bersabda:

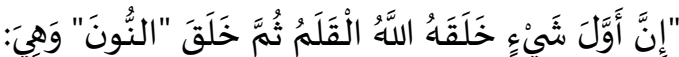

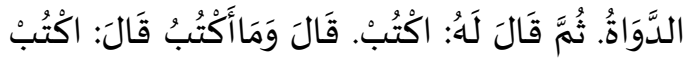

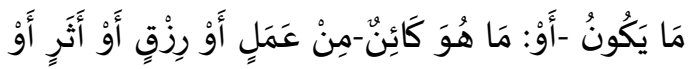

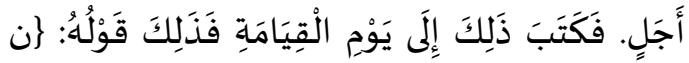

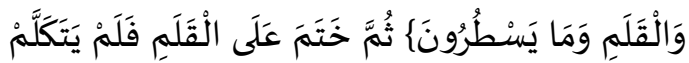

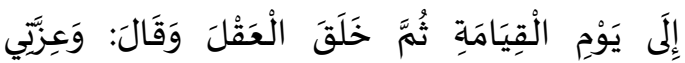

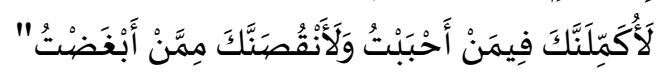

"Sesungguhnya sesuatu yang mulamula diciptakan oleh Allah adalah alqalam, kemudian Allah menciptakan nun yaitu tinta, lalu Allah berfirman kepada alqalam, "Tulislah!" Al-qalam bertanya, "Apa yang harus aku tulis?" Allah berfirman, "Tulislah segala sesuatu yang 
akan terjadi, atau segala sesuatu yang akan ada, dari amal perbuatan, atau rezeki atau jejak atau ajal." Maka al-qalam menulis semuanya itu sampai hari kiamat. Itulah yang dimaksud oleh firman Allah SWT, "Nun, demi qalam dan apa yang mereka tulis, (Al-Qalam: 1)." Kemudian al-qalam dikunci, maka ia tidak berbicara sampai hari kiamat. Kemudian Allah menciptakan akal, lalu Allah berfirman, "Demi keagungan-Ku, sungguh Aku benar-benar akan menyempurnakanmu terhadap orang yang Aku sukai, dan sungguh Aku benar-benar akan mengurangimu terhadap orang yang Aku murkai."

Nun wa al-Qalami wa yasthurun dalam Tinjauan Semiotik

a) Rule of combination/ aksis paradigmatis dan aksis sintagmatis.

b) Interaksi antartanda/metafora dan metonim

c) Heuristik dan pembacaan retroaktif/pembacaan secara semantic dan pembacaan secara hermeneutic.

\section{SIMPULAN}

Sebagaimana yang telah penulis sampaikan di awal bahwa penelitiaan ini bertujuan untuk mengetahui makna baru dari terma Nun, al-Qalam, dan Yasturun dengan menggunakan pendekatan dan teori modern yakni semiotik. Berdasarkan data yang telah penulis paparkan dalam bab pembahasan dan beberapa fakta pemaknaan dan penafsiran ayat-ayat hususnya yang menjadi konsen pada penelitian ini yang berkembang dan beredar di tengah masyarakat pengkaji alQur'an mayoritas menggunakan riwayat relatif sedikit yang melakukan kajiannya dengan menggunakan isyari atau aqliyah yang dalam perkembangan teori modern dapat digolongkan kedalan semiotik sebagaimana beberapa data yang banyak mengarah pada kedekatan keduanya. Adapun interpretasi yang lahir dari metode semiotika adalah adanya hubungan yang saling berkaitan erat antara nun, qalam dan yasturun sebagain tanda, citra bunyi yang dihasilkan darinya sebagai signifier (penanda) dan ragam makna dan pemahaman yang lahir darinya sebagai signified (petanda).

Sementara hasil analisis yang membuktikan adanya kedekatan antara metode intepretasi mutaqaddimin/ dahulu dengan intepretasi muta'akhirin/ moderen adalah sebagaimana pembacaan dengan menggunakan teori Interaksi antartanda/metafora dan metonim Nun adalah 'bak tinta'. Nun sebagai bak tinta adalah tempat menyimpan tinta, merupakan kelengkapan pena untuk menulis. Nun juga dimaknai sebagai sungai di surga. Nun dihubungkan dengan QS Al-Kahfi: 109. Adapun dengan menggunakan pembacaan teori Heuristik dan pembacaan retroaktif/pembacaan secara semantik dan pembacaan secara hermeneutik, nun adalah malaikat yang diperintah untuk menggunakan pena untuk menulis. Nun ialah malaikat yang melukis semua kejadian pada lembaran atau kanvas tempat menuangkan tulisan. Jadi, nun wa al-qalam wa ma yasthurun adalah hierarki antara Tuhan dan makhluk-Nya.

\section{DAFTAR RUJUKAN}

Al-Jahizh. 1998. al-Bayan wa al-Tabyin, ditahqiq oleh Abd Salam M. Harun. Kairo: Khanaji.

Berger, A. A. 2010. Semiotika: Tanda-tanda dalam Kebudayaan Kontemporer. Jakarta: Tiara Wacana.

Hanafi, W. 2018. Semiotika Al-Qur'an: Representasi Makna Verba Reflektif Perilaku Manusia dalam Surat AlMāūn dan Bias Sosial Keagamaan. Al-Labjah, 2 (2), 15-30.

Hasan, D. B. N. 2016. Kajian Semiotika dalam Penafsiran al-Qur'an. Prosiding. Konferensi Nasional Bahasa Arab II. Malang. 15 Oktober 2016. 549-558. 
Imran, A. 2011. Semiotika Al-Qur'an: Metode dan Aplikasi Terbadap Kisab Yusuf. Yogyakarta: Teras.

Khoirudin, A. 2014. Tafsir Gerakan alQalam. Yogyakarta: Surya Mediatama.

Lukman, F. 2015. Pendekatan Semiotika dan Penerapannya dalam Teori Asma' Al-Qur'an. Religia: Jurnal Ilmu-ilmu Keislaman, 18 (2), 207-226.

Manzhur, I. 1414 H. Lisān al-'Arab. Jilid 12. Cet. ke-3. Beirut: Dar Shadir.

Mauleman, J. H. Sumbangan dan Batas Semiotika dalam Ilmu Agama. Studi Kasus tentang Pemikiran Muhammad Arkoun. Dalam J.H. Meuleman (ed). 1996. Tradisi Kemodernan dan Metamodernisme: Memperbincangkan Pemikiran Mubammad Arkoun. Yogyakarta: LKiS.

Piliang, Y. A. 2012. Semiotika dan Hipersemiotika: Kode, Gaya, dan Matinya Makna. Bandung: Matahari.

Pradopo, R. Dj. 2002. Kritik Sastra Indonesia-Modern. Yogyakarta: Gama Media.

Rahtikawati, Y \& Rusman, D. 2013. Metodologi Tafsir Al-Qur'an. Strukturalisme, Semantik, Semiotik dan Hermeunetik. Bandung: CV Pustaka Setia.

Sunardi, St. 1996. Membaca Quran Bersama Mohammed Arkoun. Dalam J.H. Meuleman (ed). 1996. Tradisi Kemodernan dan Metamodernisme: Memperbincangkan Pemikiran Mubammad Arkoun. Yogyakarta: LKiS. 